\title{
Dopamine DI Rather than D2 Receptor Agonists Disrupt Prepulse Inhibition of Startle in Mice
}

\author{
Rebecca J Ralph-Williams', Virginia Lehmann-Masten² and Mark A Geyer*,2 \\ 'Alcohol and Drug Abuse Research Center, Harvard Medical School and McLean Hospital, Belmont, MA, USA; ${ }^{2}$ Department of Psychiatry, \\ University of California, San Diego, La Jolla, CA, USA
}

\begin{abstract}
Although substantial literature describes the modulation of prepulse inhibition (PPI) by dopamine (DA) in rats, few reports address the effects of dopaminergic manipulations on PPI in mice. We characterized the effects of subtype-specific DA agonists in the PPI paradigm to further delineate the specific influences of each DA receptor subtype on sensorimotor gating in mice. The mixed DI/D2 agonist apomorphine and the preferential DI-family agonists SKF82958 and dihydrexidine significantly disrupted PPI, with differing or no effects on startle. In contrast to findings in rats, the D2/D3 agonist quinpirole reduced startle but had no effect on PPI. Pergolide, which has affinity for D2/D3 and DI-like receptors, reduced both startle and PPI, but only at the higher, nonspecific doses. In addition, the D I-family receptor antagonist SCH23390 blocked the PPI-disruptive effects of apomorphine on PPI, but the D2-family receptor antagonist raclopride failed to alter the disruptive effect of apomorphine. These studies reveal potential species differences in the DA receptor modulation of PPI between rats and mice, where DI-family receptors may play a more prominent and independent role in the modulation of PPI in mice than in rats. Nevertheless, due to the limited selectivity of DA receptor agonists, further studies using specific receptor knockout mice are warranted to clarify the respective roles of specific DA receptor subtypes in modulating PPI in mice. Neuropsychopharmacology (2003) 28, 108-1 I8. doi:10.1038/sj.npp. 1300017
\end{abstract}

Keywords: dopamine; prepulse inhibition; startle; mice; DI receptor; D2 receptor

\section{INTRODUCTION}

When a low-intensity prepulse precedes a startling stimulus, the subsequent startle response is reduced. This sensorimotor gating mechanism is termed prepulse inhibition (PPI) and is demonstrable across species from mice to humans (Graham, 1975; Hoffman and Ison, 1980). PPI is disrupted in certain neuropsychiatric disorders that are characterized by an inability to filter or 'gate' incoming sensory information, such as schizophrenia (Braff et al, 2001). The deficits in PPI observed in schizophrenia patients can be mimicked in rats by the administration of dopamine (DA) agonists. Both typical and atypical antipsychotic drugs reverse these DA agonist-induced deficits in PPI (Geyer et al, 2001; Swerdlow and Geyer, 1993). An improved understanding of the specific roles of DA receptor subtypes in the modulation of PPI may help to elucidate key elements of the pathophysiology of neuropsychiatric disorders characterized by gating deficiencies.

In the present studies, subtype-specific DA ligands were tested in the PPI paradigm to further characterize the specific functions of each DA receptor subtype in mice.

* Correspondence: MA Geyer, Department of Psychiatry, University of California, San Diego, 9500 Gilman Drive, La Jolla, CA 92093-0804, USA. Tel: + 619543 3582, Fax: + I 619543 2493, E-mail:mgeyer@ucsd.edu

Received 12 April 2002; revised 17 June 2002; accepted I 8 June 2002
There are two classes of DA receptors that are categorized by their ability to stimulate (D1-like) or inhibit (D2-like) adenylyl cyclase (Kebabian and Calne, 1979). The D1 family of receptors includes the D1 and D5 subtypes, while the D2 family consists of the D2, D3, and D4 receptor subtypes. Previous studies have established a contribution of DA and its receptor subtypes to the modulation of PPI in rats (Geyer et al, 2001). The vast majority of evidence indicates that the D2 rather than the D1 receptors are involved in the regulation of PPI in rats, possibly in synergism with D1 receptors.

Although there have been numerous reports of the effects of DA perturbations in the rat literature, there are relatively few reports on the DA receptor pharmacology of PPI in mice (Geyer et al, in press). DA agonists such as amphetamine and apomorphine produce deficits in PPI in mice (Curzon and Decker, 1998; Dulawa and Geyer, 1996; Ralph et al, 1999). Amphetamine disrupts PPI in both DA D3 and D4, but not D2, receptor knockout mice, indicating that the D2 receptor is essential for amphetamine to disrupt PPI in mice (Ralph et al, 1999). Furthermore, DA transporter knockout mice, which have hyperdopaminergic tone, have deficits in PPI that can be reversed by the D2 receptor antagonist raclopride (Ralph et al, 2001). These reports corroborate previous findings in rats and suggest that there may be comparable dopaminergic mechanisms regulating PPI in rats and mice. 
To further characterize the effects of direct DA agonists on PPI in mice, we tested male $\mathrm{C} 57 \mathrm{BL} / 6 \mathrm{~J}$ mice (many congenic knockout lines are created on this strain of mouse) with the D1/D2 agonist apomorphine, the D1-family agonists SKF82958 and dihydrexidine, the D2/D3 agonist quinpirole, and the mixed DA agonist pergolide. Experiments using the D1 receptor antagonist SCH23390 and the D2 receptor antagonist raclopride were also conducted against both apomorphine and pergolide. In some experiments, we also tested male 129 S6 mice, a strain of mouse commonly used to create gene knockout mice, and cohorts of female $\mathrm{C} 57 \mathrm{BL} / 6 \mathrm{~J}$ mice. Based on the rat literature and previous findings in mice, we hypothesized that the mixed D1/D2 and the preferential D2 agonists would disrupt PPI in mice.

\section{METHODS}

\section{Animals}

Animal studies were approved by the University of California, San Diego Animal Use and Care Committee and conducted in accordance with the Guide for the Care and Use of Laboratory Animals as adopted and promulgated by the National Institute of Health. Mice from each experiment were group-housed in a climate-controlled animal colony with a reversed day/night cycle (12 h:12 h). All behavioral testing started at approximately 8-9 weeks of age and occurred during the animals' dark cycle. Food (Harlan Teklab, Madison, WI) and water were available throughout the experiments, except during behavioral testing.

\section{Drug Experiments}

All injections were given at a volume of $5 \mathrm{ml} / \mathrm{kg}$ body weight 10 min prior to the onset of the PPI test session unless otherwise stated. Except when otherwise noted, a betweensubjects design was used for each study, with the dose of drug or vehicle being assigned in a pseudo-random order (balancing the dose of drug with the chamber assignment).

Apomorphine A total of 48 male C57BL/6J (Jackson Laboratories, Bar Harbor, ME) and 48 male $129 \mathrm{~S} 6$ mice (formerly known as 129SvEv, Taconic Labs, Germantown, $\mathrm{NY})$ were used in the apomorphine experiments $(n=12$ per treatment group). Apomorphine hydrochloride was obtained from Sigma (St Louis, MO) and was dissolved in $0.1 \%$ ascorbic acid. Based on previous studies (Curzon and Decker, 1998; Dulawa and Geyer, 1996), the test doses included $2.5,5.0$ or $7.5 \mathrm{mg} / \mathrm{kg}$ apomorphine, or vehicle, injected subcutaneously.

SKF82958 A total of 48 male C57BL/6J and 48 male 129S6 mice were used in the SKF82958 experiments ( $n=12$ per treatment group). SKF82958 hydrobromide was obtained from Sigma (St Louis, MO) and was dissolved in sterile water. The $\mathrm{C} 57 \mathrm{BL} / 6 \mathrm{~J}$ mice were tested with $0.03,0.1,0.3,1.0$ or $3.0 \mathrm{mg} / \mathrm{kg}$ SKF82958, or vehicle, while the $129 \mathrm{~S} 6$ mice were tested with $0.03,0.1$ or $0.3 \mathrm{mg} / \mathrm{kg}$ SKF82958, or vehicle. All injections were given intraperitoneally.
Dihydrexidine In all, $36 \mathrm{C} 57 \mathrm{BL} / 6 \mathrm{~J}$ mice were used in the dihydrexidine experiments ( $n=9$ per treatment group). Dihydrexidine is a selective D1-family receptor agonist and has been shown to be behaviorally active in both rats and mice (Darney et al, 1991; Mottola et al, 1992). Dihydrexidine hydrochloride was generously provided by Dr David Nichols (Purdue University) and was dissolved in $0.1 \%$ ascorbic acid. The mice were treated subcutaneously with $1.0,3.0$ or $10.0 \mathrm{mg} / \mathrm{kg}$ dihydrexidine, or vehicle.

Quinpirole A total of 102 male C57BL/6J $(n=9$ per treatment group in the first quinpirole study; $n=10$ for vehicle and $n=8$ per drug group for the second quinpirole study) and 44 male 12956 mice ( $n=11$ per treatment group) were used in the quinpirole experiments. Quinpirole hydrochloride was obtained from Sigma (St Louis, MO) and was dissolved in $0.9 \%$ saline. In the first quinpirole experiments, both the C57BL/6J and 129S6 mice received $5.0,7.5$ or $10.0 \mathrm{mg} / \mathrm{kg}$ quinpirole, or vehicle, intraperitoneally. In the more extensive quinpirole experiment, male C57BL/6J mice received $0.01,0.03,0.1,0.3,1.0,3.0$ or $10.0 \mathrm{mg} / \mathrm{kg}$ quinpirole, or vehicle. In a separate experiment, 30 female C57BL/6J mice ( $n=7-8$ per treatment group) received $0.03,0.3$ or $3.0 \mathrm{mg} / \mathrm{kg}$ quinpirole, or vehicle.

Pergolide In all, 50 male C57BL/6J mice ( $n=10$ per treatment group) were used in the first pergolide experiment. Pergolide has been described as a putative D2-family agonist, but there are reports that it also has affinity for the D1 receptor (Miyagi et al, 1996; Perachon et al, 1999). Pergolide mesylate was obtained from Sigma (St Louis, MO) and was dissolved in $0.9 \%$ saline. The mice received intraperitoneal injections of either 1.25, 2.5, 5.0 or $10.0 \mathrm{mg} / \mathrm{kg}$ pergolide, or vehicle. In the second pergolide study, 37 C57BL/6J mice ( $n=12-13$ per treatment group) were given either 10.0 or $20.0 \mathrm{mg} / \mathrm{kg}$ pergolide, or vehicle.

Apomorphine vs SCH23390 A total of 48 male C57BL/6J mice (Jackson Laboratories, Bar Harbor, ME) were used in the apomorphine $v s \mathrm{SCH} 23390$ experiment $(n=12$ per treatment group). SCH23390 hydrochloride was obtained from Sigma (St Louis, MO). Apomorphine was dissolved in $0.1 \%$ ascorbic acid and $\mathrm{SCH} 23390$ was dissolved in water. Based on previous findings with apomorphine and SCH23390 (see Dulawa and Geyer, 1996; Ralph et al, 2001), mice were pretreated subcutaneously with either vehicle or $1.0 \mathrm{mg} / \mathrm{kg} \mathrm{SCH} 2339010 \mathrm{~min}$ prior to treatment with either vehicle or $5.0 \mathrm{mg} / \mathrm{kg}$ apomorphine.

Apomorphine vs raclopride In all, 50 male C57BL/6J mice (Jackson Laboratories, Bar Harbor, ME) were used in the apomorphine $v s$ raclopride experiment $(n=12-13$ per treatment group). Raclopride tartrate was obtained from Sigma (St Louis, MO) and was dissolved in $0.9 \%$ saline. Mice were pretreated intraperitoneally with either $3.0 \mathrm{mg} / \mathrm{kg}$ raclopride (see Ralph et al (2001) for dose information) or vehicle $10 \mathrm{~min}$ prior to an injection of vehicle or $5.0 \mathrm{mg} / \mathrm{kg}$ apomorphine.

Pergolide vs SCH23390 or raclopride Altogether 60 male C57BL/6J mice (Jackson Laboratories, Bar Harbor, ME) were used in the pergolide $v s \mathrm{SCH} 23390$ or raclopride 
experiment ( $n=10$ per treatment group). Based on results from the pergolide study and the antagonist studies described above, mice were pretreated with either vehicle, $1.0 \mathrm{mg} / \mathrm{kg} \mathrm{SCH} 23390$, or $3.0 \mathrm{mg} / \mathrm{kg}$ raclopride $10 \mathrm{~min}$ before receiving either vehicle or $10.0 \mathrm{mg} / \mathrm{kg}$ pergolide.

\section{Apparatus}

Startle reactivity was measured using four startle chambers (SR-LAB, San Diego Instruments, San Diego, CA). Each chamber consisted of a clear nonrestrictive Plexiglas cylinder resting on a platform inside a ventilated box. A high-frequency loudspeaker inside the chamber produced both a continuous background noise of $65 \mathrm{~dB}$ and the various acoustic stimuli. Vibrations of the Plexiglas cylinder caused by the whole-body startle response of the animal were transduced into analog signals by a piezoelectric unit attached to the platform. These signals were then digitized and stored by a computer. A total of 65 readings were taken at 1-ms intervals, starting at stimulus onset, and the average amplitude was used to determine the startle response. Sound levels in dB SPL (A scale) were measured as described previously (Dulawa et al, 1997). The SR-LAB calibration unit was used routinely to ensure consistent stabilimeter sensitivity between test chambers and over time (Geyer and Swerdlow, 1998).

\section{PPI Session}

All PPI test sessions consisted of startle trials (PULSEALONE), prepulse trials (PREPULSE+PULSE), and no-stimulus trials (NOSTIM). The PULSE-ALONE trial consisted of a $40-\mathrm{ms} 120-\mathrm{dB}$ pulse of broadband noise. PPI was measured by PREPULSE+PULSE trials that consisted of a $20-\mathrm{ms}$ noise prepulse, a $100 \mathrm{~ms}$ delay, and then a $40-\mathrm{ms}, 120-\mathrm{dB}$ startle pulse $(120 \mathrm{~ms}$ onset to onset interval). The acoustic prepulse intensities were 4,8 , and $16 \mathrm{~dB}$ above the $65-\mathrm{dB}$ background noise (ie 69, 73, and $81 \mathrm{~dB})$. The NOSTIM trial consisted of background noise only. The test session began and ended with five presentations of the PULSE-ALONE trial; in between, each acoustic or NOSTIM trial type was presented 10 times in a pseudorandom order. There was an average of $15 \mathrm{~s}$ (range: 12-30 s) between trials. Mice were assigned to receive a dose of drug or vehicle (balanced for startle chamber assignment and treatment) in a pseudo-random order. The mice were placed in the startle chambers immediately after agonist injection, where a 65-dB background noise level was presented for a 10-min acclimation period and continued throughout the test session.

The amount of PPI was calculated as a percentage score for each acoustic prepulse trial type: $\%$ PPI $=100-\{[$ (startle response for PREPULSE+PULSE)/(startle response for PULSE-ALONE) $\times 100\}$. Acoustic startle magnitude was calculated as the average response to all of the PULSEALONE trials, excluding the first and last blocks of five PULSE-ALONE trials. For brevity, the main effects of prepulse intensity (which were always significant) will not be discussed. Data from the NOSTIM trials are not included in the Results section, because the values were negligible relative to values on trials containing startle stimuli.

\section{Statistical Analyses}

In the statistical analyses, drug treatment was a betweensubjects variable and prepulse intensity was a withinsubjects variable. ANOVAs were used to compare means and Tukey's tests were used for post hoc analysis. The computations were carried out using the BMDP statistical software (Statistical Solutions Inc., Saugus, MA).

\section{RESULTS}

\section{Apomorphine}

As in previous reports (Curzon and Decker, 1998; Dulawa and Geyer, 1996), the mixed DA D1/D2 receptor agonist apomorphine significantly disrupted PPI in C57BL/6J mice

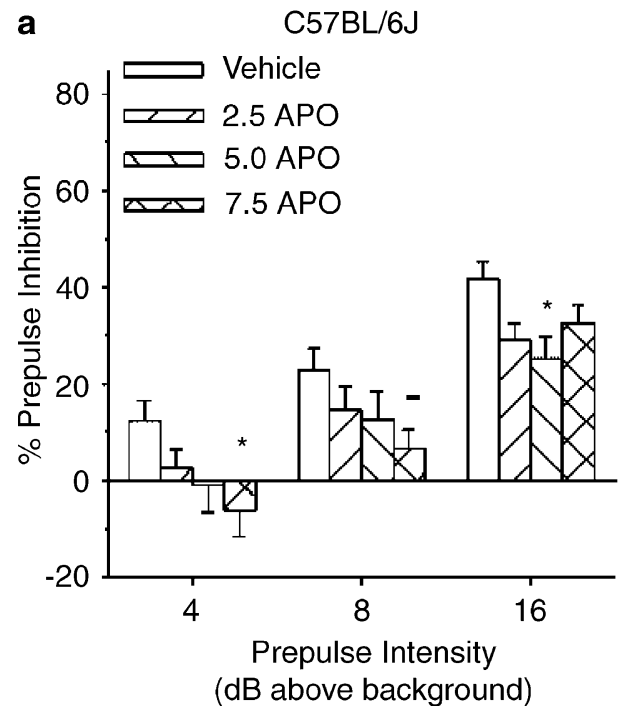

b $129 S 6$

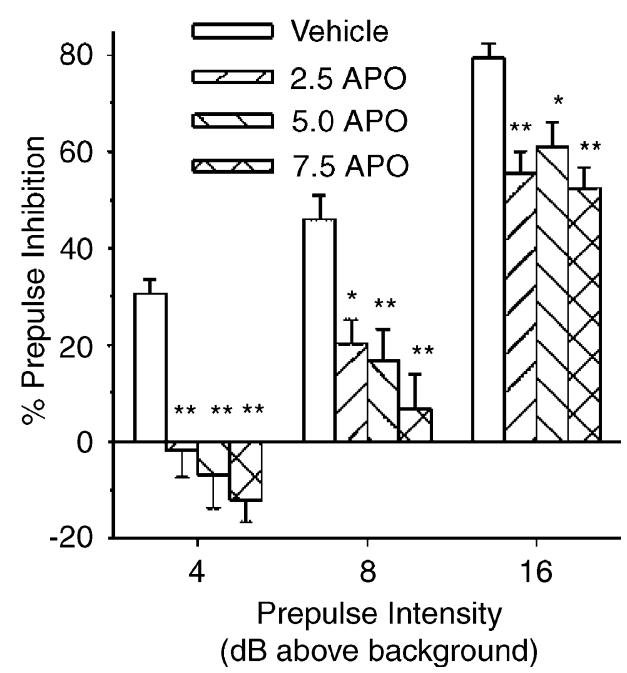

Figure I PPI levels in C57BL/6) mice and 12956 mice after pretreatment with vehicle (0.1\% ascorbic acid, open bars) or APO (2.5-7.5 mg/kg apomorphine, hatched bars). The mixed DI/D2 agonist apomorphine significantly disrupted PPI in both the (a) C57BL/6J and (b) 129S6 mice. Values represent mean \% PPI \pm SEM and prepulse intensities are above the $65 \mathrm{~dB}$ background noise. $-p<0.10, * p<0.05$, $* * p<0.01$ compared to vehicle control. 
$(\mathrm{F}(3,44)=2.8, p<0.05)$ (see Figure 1a). Apomorphine also significantly reduced acoustic startle response in the C57BL/ 6J mice $(\mathrm{F}(3,44)=19.1, p<0.01)$. Further analyses indicated that startle response was decreased at each dose of apomorphine tested $(p<0.01)$ (see Table 1$)$.

The 129S6 mice were also tested to further characterize the effects of apomorphine in mice. As with the C57BL/6J mice, there was a main effect of apomorphine on PPI $(\mathrm{F}(3,43)=13.8, \quad p<0.001)$. The effects of apomorphine appeared to be more pronounced in the 129S6 than in the C57BL/6J mice; post hoc testing showed that each dose of apomorphine significantly disrupted PPI at each prepulse intensity (see Figure 1b). Similar to the C57BL/6J mice, there was a main effect of drug on startle reactivity $(\mathrm{F}(3,43)=29.9, \quad p<0.001)$; every dose of apomorphine tested significantly reduced the startle response in the 129S6 mice $(p<0.01)$ (see Table 1$)$.

\section{SKF82958}

Similar to the effects of high doses of SKF82958 in rats (ie $5 \mathrm{mg} / \mathrm{kg}$ ) (Swerdlow et al, 2000; Wan et al, 1996), the DA D1-family agonist SKF82958 significantly lowered PPI in C57BL/6J mice $(\mathrm{F}(5,66)=6.7, p<0.001)$. As seen in Figure 2a, even a dose as low as $0.3 \mathrm{mg} / \mathrm{kg}$ SKF82958 significantly disrupted PPI in the C57BL/6J mice at each prepulse intensity. SKF82958 also significantly reduced startle magnitudes in the $\mathrm{C} 57 \mathrm{BL} / 6 \mathrm{~J}$ mice $(\mathrm{F}(5,66)=5.4$, $p<0.001)$. The startle response was lowered in the C57BL/6J mice at $0.3,1.0$ and $3.0 \mathrm{mg} / \mathrm{kg} \mathrm{SKF82958} \mathrm{(see} \mathrm{Table} \mathrm{1).}$

As in the C57BL/6J mice, there was also a significant main effect of SKF82958 on PPI in the 129 S6 mice $(\mathrm{F}(3,43)=9.2, p<0.001)$. The $0.3 \mathrm{mg} / \mathrm{kg}$ dose of SKF82958 significantly disrupted PPI at both the 4 and $16 \mathrm{~dB}$ prepulse intensities, and there was a trend toward a disruption at the $8-\mathrm{dB}$ prepulse intensity (see Figure $2 \mathrm{~b}$ ). SKF82958 also affected startle response in the 129 S6 mice $(\mathrm{F}(3,43)=3.2, p<0.05)$, but only the $0.3 \mathrm{mg} / \mathrm{kg}$ dose of
SKF82958 significantly reduced the startle response (see Table 1).

\section{Dihydrexidine}

When male C57BL/6J mice were treated with the selective DA D1-family agonist dihydrexidine, there was a significant main effect of drug treatment on PPI $(\mathrm{F}(3,31)=3.4$, $p<0.05)$. PPI was significantly disrupted by the $10.0 \mathrm{mg} /$

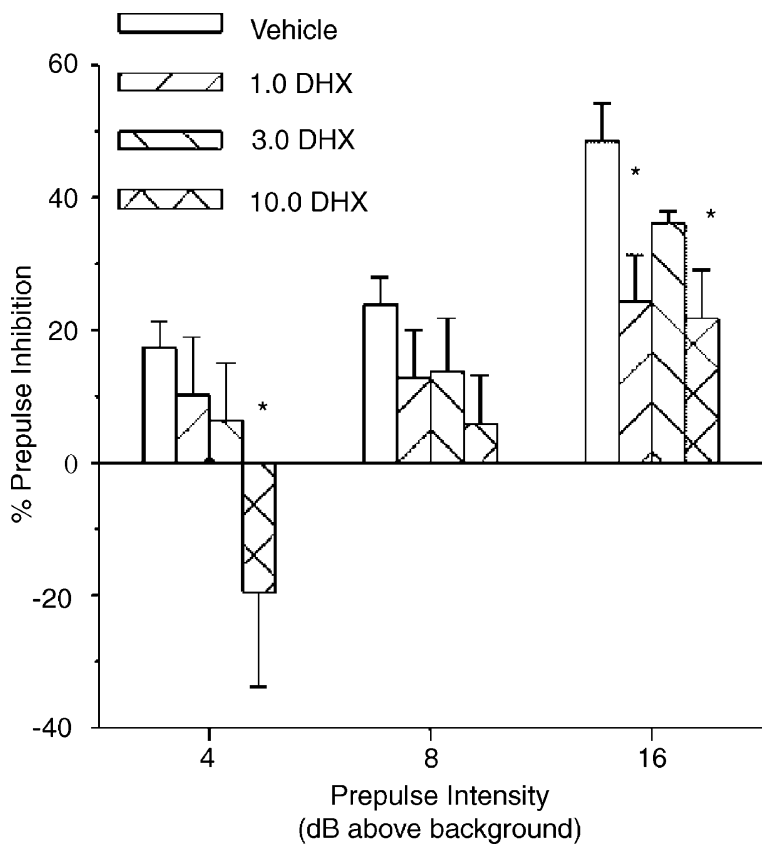

Figure 3 Levels of PPI in C57BL/6) with vehicle (0.1\% ascorbic acid, open bars) or DHX (1.0-10.0 mg/kg dihydrexidine, hatched bars). The direct D I-family receptor agonist dihydrexidine significantly reduced PPI in male C57BL/6). Values represent mean \% PPI \pm SEM and prepulse intensities are above the $65 \mathrm{~dB}$ background noise. $* p<0.05$ compared to vehicle control.
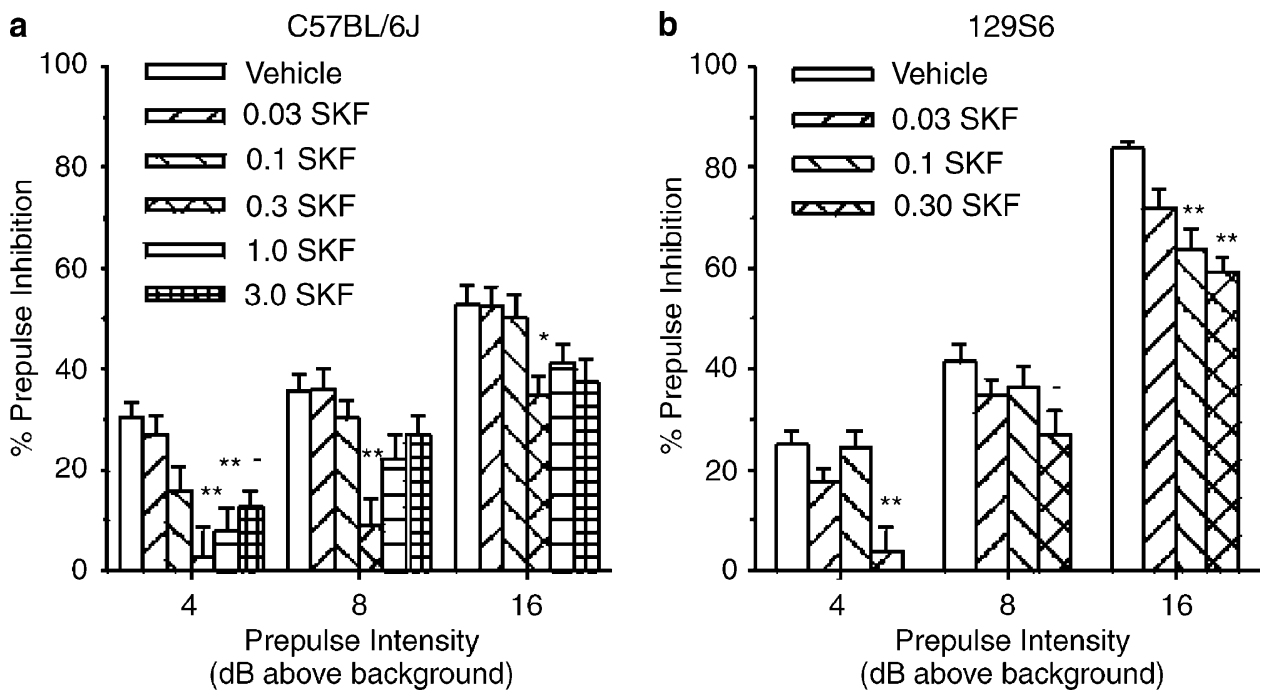

Figure 2 PPI levels in C57BL/6) and I29S6 mice after pretreatment with vehicle (water, open bars) or SKF (0.03-3.0 mg/kg SKF82958, hatched bars). The direct DI-family receptor agonist SKF82958 significantly disrupted PPI in both the (a) C57BL/6) and (b) I29S6 mice. Values represent mean \% PPI \pm SEM and prepulse intensities are above the $65 \mathrm{~dB}$ background noise. $-p<0.10, * p<0.05,{ }^{*} * p<0.01$ compared to vehicle control. 
Table I Effects of DA Agonists on Acoustic Startle Reactivity in C57BL/6J and 129S6 Mice

\begin{tabular}{|c|c|c|}
\hline Drug & C57BL/6J & $129 S 6$ \\
\hline \multicolumn{3}{|c|}{ Apomorphine, male } \\
\hline Vehicle & $163.8 \pm 9.5$ & $206.1 \pm 18.6$ \\
\hline $2.5 \mathrm{mg} / \mathrm{kg}$ & $95.0 \pm 5.6 * * *$ & $76.6 \pm 10.9 * *$ \\
\hline $5.0 \mathrm{mg} / \mathrm{kg}$ & $90.9 \pm 9.5 * *$ & $75.0 \pm 5.4^{* * *}$ \\
\hline 7.5 mg/kg & $90.3 \pm 7.6 * *$ & $85.4 \pm 7.2^{* * *}$ \\
\hline \multicolumn{3}{|c|}{ SKF82958, male } \\
\hline Vehicle & $147.4 \pm 9.5$ & $166.8 \pm 7.5$ \\
\hline $0.03 \mathrm{mg} / \mathrm{kg}$ & $135.8 \pm 10.2$ & $155.4 \pm 14.4$ \\
\hline $0.10 \mathrm{mg} / \mathrm{kg}$ & $133.1 \pm 10.7$ & $137.9 \pm 17.2$ \\
\hline $0.30 \mathrm{mg} / \mathrm{kg}$ & $102.6 \pm 6.9 * *$ & $1 \mid 4.0 \pm 8.4 *$ \\
\hline $1.0 \mathrm{mg} / \mathrm{kg}$ & $103.9 \pm 7.6 *$ & Not tested \\
\hline $3.0 \mathrm{mg} / \mathrm{kg}$ & $101.4 \pm 7.2 * *$ & Not tested \\
\hline \multicolumn{3}{|c|}{ Dihydrexidine, male } \\
\hline Vehicle & $97.0 \pm 13.5$ & Not tested \\
\hline $1.0 \mathrm{mg} / \mathrm{kg}$ & $83.0 \pm 7.4$ & Not tested \\
\hline $3.0 \mathrm{mg} / \mathrm{kg}$ & $83.8 \pm 13.5$ & Not tested \\
\hline $10.0 \mathrm{mg} / \mathrm{kg}$ & $94.6 \pm 12.5$ & Not tested \\
\hline \multicolumn{3}{|c|}{ Quinpirole, male } \\
\hline Vehicle & $132.1 \pm 9.6$ & $164.9 \pm 14.5$ \\
\hline $5.0 \mathrm{mg} / \mathrm{kg}$ & || $4.3 \pm \mid 3.8$ & $85.1 \pm 12.9 * *$ \\
\hline $7.5 \mathrm{mg} / \mathrm{kg}$ & $105.9 \pm 12.0$ & $73.6 \pm 11.1 * * *$ \\
\hline $10.0 \mathrm{mg} / \mathrm{kg}$ & $82.6 \pm 8.0 *$ & $94.0 \pm 13.1$ *** \\
\hline \multicolumn{3}{|c|}{ Quinpirole, female } \\
\hline Vehicle & $106.6 \pm 18.1$ & Not tested \\
\hline $0.03 \mathrm{mg} / \mathrm{kg}$ & $1 \mid 2.1 \pm 11.0$ & Not tested \\
\hline $0.3 \mathrm{mg} / \mathrm{kg}$ & || $\mid .5 \pm 15.8$ & Not tested \\
\hline $3.0 \mathrm{mg} / \mathrm{kg}$ & $85.7 \pm 10.3$ & Not tested \\
\hline \multicolumn{3}{|l|}{ Pergolide, male } \\
\hline Vehicle & $261.4 \pm 18.3$ & Not tested \\
\hline $1.25 \mathrm{mg} / \mathrm{kg}$ & $247.7 \pm 26.2$ & Not tested \\
\hline $2.5 \mathrm{mg} / \mathrm{kg}$ & $213.0 \pm 31.2$ & Not tested \\
\hline $5.0 \mathrm{mg} / \mathrm{kg}$ & $150.1 \pm 17.4 *$ & Not tested \\
\hline $10.0 \mathrm{mg} / \mathrm{kg}$ & $148.2 \pm 21.9 *$ & Not tested \\
\hline \multicolumn{3}{|l|}{ Pergolide, male } \\
\hline Vehicle & $86.3 \pm 13.0$ & Not tested \\
\hline $10.0 \mathrm{mg} / \mathrm{kg}$ & $74.7 \pm 8.9$ & Not tested \\
\hline $20.0 \mathrm{mg} / \mathrm{kg}$ & $56.3 \pm 12.3$ & Not tested \\
\hline
\end{tabular}

Values (arbitrary units) represent mean startle magnitude \pm SEM. $* p<0.05$, **⿻丷木 $p<0.0$ l compared to vehicle control.

$\mathrm{kg}$ dose at both the 4- and 16- $\mathrm{dB}$ prepulse intensities, while $1.0 \mathrm{mg} / \mathrm{kg}$ reduced PPI at the $16-\mathrm{dB}$ prepulse intensity $(p<0.05)$ (see Figure 3). Treatment with dihydrexidine had no effect on startle reactivity in mice (see Table 1).

\section{Quinpirole}

In contrast to reports in the rat literature (Caine et al, 1995; Geyer et al, 1990; Peng et al, 1990; Varty and Higgins, 1998), the DA D2/D3 agonist quinpirole did not significantly disrupt PPI in either male C57BL/6J or 129S6 mice (see Figure $4 \mathrm{a}$ and $\mathrm{b}$ ) or in female C57BL/6J mice (see Table 2). In light of this discrepancy in effects between species, we conducted 15 additional experiments with quinpirole, in which a variety of different stimulus parameters, preinjection intervals, routes of administration, or doses were utilized (data not shown). Despite the range of these studies, no consistent effects of quinpirole on PPI were identified in the C57BL/6J mice (see Table 2 for subset of data from these experiments).

Quinpirole did have significant effects on acoustic startle response in both the male $\mathrm{C} 57 \mathrm{BL} / 6 \mathrm{~J}(\mathrm{~F}(3,33)=3.7, p<0.05)$ and $129 \mathrm{~S} 6$ mice $(\mathrm{F}(3,40)=10.2, p<0.001)$. Acoustic startle reactivity was reduced in the C57BL/6J mice at $10 \mathrm{mg} / \mathrm{kg}$ quinpirole, and at each dose tested in the 129 S6 mice (see Table 1). However, the effects of quinpirole on startle reactivity were not consistent in the C57BL/6J mice. In the second quinpirole dose-response study, quinpirole had no significant effect on startle response (data not shown). Unlike the male mice, quinpirole had no significant effect on the startle response of the female C57BL/6J mice (see Table 1).

\section{Pergolide}

In addition to quinpirole, other putative D2-family agonists disrupt PPI in rats, including bromocriptine, ropinirole, and pergolide (Geyer et al, 2001; Swerdlow et al, 1998). After finding no significant effect of quinpirole, a different cohort of male C57BL/6J mice was tested with the mixed DA agonist pergolide. Unlike the previous quinpirole results, there was a trend toward a significant effect of pergolide at the higher doses on PPI $(\mathrm{F}(4,43)=2.4, p=0.07$ ) (see Figure 5a). Indeed, an exploratory $t$-test comparing the vehicle and $10 \mathrm{mg} / \mathrm{kg}$ pergolide groups suggested a significant reduction in PPI by pergolide. Based on this trend, we conducted a second experiment, testing only 10 and $20 \mathrm{mg} / \mathrm{kg}$ pergolide. As shown in Figure $5 \mathrm{~b}$, there was a significant main effect of pergolide on PPI $(\mathrm{F}(2,34)=5.4$, $p<0.01)$. Pergolide $(10.0 \mathrm{mg} / \mathrm{kg})$ significantly lowered PPI at the $8-\mathrm{dB}$ prepulse intensity $(p<0.01)$ and tended to lower PPI with 4 or $16-\mathrm{dB}$ prepulses, whereas $20 \mathrm{mg} / \mathrm{kg}$ pergolide only decreased PPI at the 8- and $16-\mathrm{dB}$ prepulse intensities $(p<0.05)$.

Treatment with pergolide significantly reduced the acoustic startle response $(\mathrm{F}(4,43)=5.1, p<0.01$ ) (see Table 1), particularly at the 5.0 and $10.0 \mathrm{mg} / \mathrm{kg}$ doses in the first experiment. However, these effects on startle response were somewhat inconsistent as neither 10 nor $20 \mathrm{mg} / \mathrm{kg}$ pergolide altered the acoustic startle response significantly in the second pergolide study (see Table 1).

\section{Apomorphine vs SCH23390}

To investigate the role of the D1 receptor in the effects of apomorphine on PPI, mice were pretreated with the D1family receptor antagonist SCH23390. There were significant main effects of both SCH23390 $(\mathrm{F}(1,44)=9.2, p<0.01)$ and apomorphine $(\mathrm{F}(1,44)=4.0, p<0.05)$ on PPI, and there was a significant interaction between SCH23390 and apomorphine treatments (see Figure 6a). Post hoc analyses revealed that apomorphine significantly lowered PPI and SCH23390 blocked this disruption. As with the studies above, apomorphine also had significant effects on startle response $(\mathrm{F}(1,44)=12.1, p<0.001) ; 5 \mathrm{mg} / \mathrm{kg}$ apomorphine significantly lowered the startle response $(p<0.01)$ (see Table 3). 
a

C57B/6J

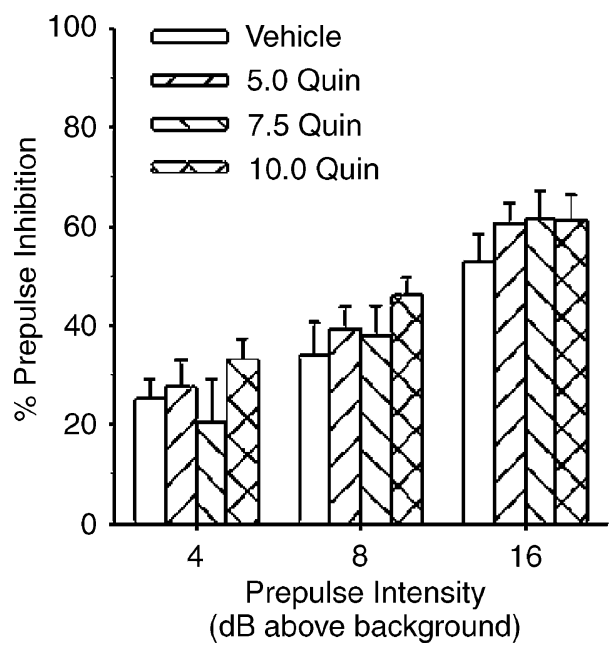

b

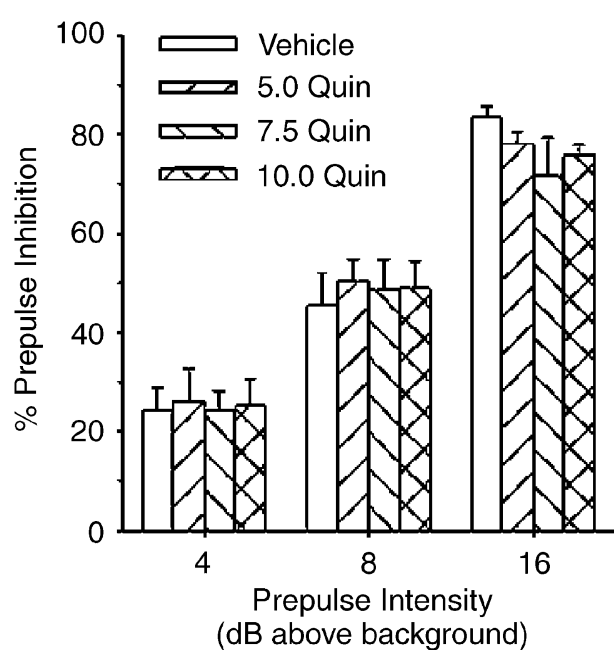

Figure 4 PPI levels in C57BL/6) and I29S6 mice after treatment with vehicle (0.9\% saline, open bars) or QUIN (5.0-10.0 mg/kg quinpirole, hatched bars). The direct D2/D3 receptor agonist quinpirole had no significant effect on PPI in either the (a) C57BL/6) on (b) I29S6 mice. Values represent mean \% $\mathrm{PPI} \pm$ SEM and prepulse intensities are above the $65 \mathrm{~dB}$ background noise.

Table 2 Effects of Quinpirole on PPI in Female and Male C57BL 6) Mice

\begin{tabular}{lccc}
\hline Treatment group & $\mathbf{4 ~ d B}$ & $\mathbf{8 ~ d B}$ & $\mathbf{1 6 ~ d B}$ \\
\hline Quinpirole, female C57BL/6] & & & \\
Vehicle & $8.9 \pm 3.8$ & $19.5 \pm 7.2$ & $39.5 \pm 5.6$ \\
$0.03 \mathrm{mg} / \mathrm{kg}$ & $4.4 \pm 8.5$ & $11.7 \pm 9.3$ & $28.9 \pm 9.3$ \\
$0.3 \mathrm{mg} / \mathrm{kg}$ & $10.8 \pm 6.7$ & $16.4 \pm 3.7$ & $43.6 \pm 7.7$ \\
$3.0 \mathrm{mg} / \mathrm{kg}$ & $9.4 \pm 9.3$ & $15.6 \pm 8.5$ & $36.7 \pm 8.5$ \\
& & & \\
Quinpirole, male C57BL/6] & & & \\
Vehicle & $27.8 \pm 3.3$ & $39.9 \pm 5.0$ & $61.8 \pm 2.9$ \\
$0.01 \mathrm{mg} / \mathrm{kg}$ & $29.7 \pm 4.8$ & $47.3 \pm 4.5$ & $68.3 \pm 3.8$ \\
$0.03 \mathrm{mg} / \mathrm{kg}$ & $30.5 \pm 5.5$ & $43.9 \pm 5.3$ & $62.7 \pm 4.1$ \\
$0.1 \mathrm{mg} / \mathrm{kg}$ & $32.6 \pm 2.0$ & $48.4 \pm 2.4$ & $64.0 \pm 2.6$ \\
$0.3 \mathrm{mg} / \mathrm{kg}$ & $28.2 \pm 4.8$ & $39.9 \pm 6.0$ & $58.0 \pm 5.8$ \\
$1.0 \mathrm{mg} / \mathrm{kg}$ & $25.7 \pm 2.6$ & $37.6 \pm 3.6$ & $60.3 \pm 2.6$ \\
$3.0 \mathrm{mg} / \mathrm{kg}$ & $24.7 \pm 4.3$ & $36.1 \pm 3.7$ & $55.5 \pm 4.6$ \\
$10.0 \mathrm{mg} / \mathrm{kg}$ & $28.8 \pm 2.8$ & $42.4 \pm 3.4$ & $59.0 \pm 2.1$ \\
\hline
\end{tabular}

Prepulse levels are above 65-dB background noise. Values represent mean \% $\mathrm{PPI} \pm \mathrm{SEM}$.

\section{Apomorphine vs Raclopride}

The D2-family antagonist, raclopride, was next used to ascertain if the D2 receptor had a role in the disruptive effects of the mixed D1/D2 receptor agonist apomorphine. Mice were pretreated with $3 \mathrm{mg} / \mathrm{kg}$ raclopride and then treated with $5 \mathrm{mg} / \mathrm{kg}$ apomorphine. As before, there was a significant main effect of apomorphine on PPI $(\mathrm{F}(1,46)=19.5, p<0.01)$, but there was no main effect of, nor interactions with, raclopride (see Figure 6b). However, there were main effects of both raclopride and apomorphine on startle response $(\mathrm{F}(1,46)=9.1, p<0.01$ and $\mathrm{F}(1,46)=5.5$, $p<0.05$, respectively), although post hoc tests showed that only apomorphine significantly lowered startle relative to vehicle controls (see Table 3). A significant interaction between raclopride and apomorphine $(\mathrm{F}(1,46)=15.1$, $p<0.001)$ suggested the D2 antagonist blocked the startlereducing effects of apomorphine in mice.

\section{Pergolide $v s \mathrm{SCH} 23390$ or Raclopride}

In a final study, both SCH23390 and raclopride were used against the mixed DA agonist pergolide, based on the effects on PPI seen above. There was a significant main effect of pergolide on PPI $(\mathrm{F}(1,54)=14.7, p<0.001)$, and there was an interaction between pergolide and the antagonists on PPI $(\mathrm{F}(2,54)=9.1, p<0.001)$ (see Figure 7). Pergolide $(10 \mathrm{mg} /$ $\mathrm{kg})$ significantly decreased PPI at each prepulse intensity $(p<0.01)$; SCH23390 blocked the PPI-disruptive effects of pergolide at all intensities, while raclopride only blocked the effects of the mixed agonist at the 8- and 16-dB prepulse intensities. As in the previous experiment, there was a significant main effect of pergolide on the startle response $(\mathrm{F}(1,54)=15.9, p<0.001)$, and there was a significant effect with the antagonists $(\mathrm{F}(2,54)=4.5, p<0.05)$ (see Table 3 ).

\section{DISCUSSION}

The present studies extend previous reports of disruptions in PPI produced by direct DA agonists in rats by examining the effects of these compounds on PPI in mice. Confirming previous findings in both rats and mice, the DA D1/D2 receptor agonist apomorphine significantly reduced PPI in two different inbred strains of mice. However, in other respects, differences in drug effects on PPI were found in mice compared to the previous findings in rats. First, direct stimulation of the D1 receptor by low and relatively specific doses of the direct D1-family agonists SKF82958 and dihydrexidine significantly reduced PPI in mice. Second, the direct DA D2/D3 agonist quinpirole failed to disrupt PPI in two different strains of mice, while the mixed DA agonist pergolide significantly lowered PPI in the C57BL/6J mice, although only at the higher doses tested. In further experiments designed to characterize the role of the D1 and $\mathrm{D} 2$ receptor subtypes in the modulation of PPI in mice, the PPI-disruptive effects of apomorphine were blocked in C57BL/6J mice pretreated with the D1 receptor antagonist SCH23390, but not the D2 receptor antagonist raclopride. 

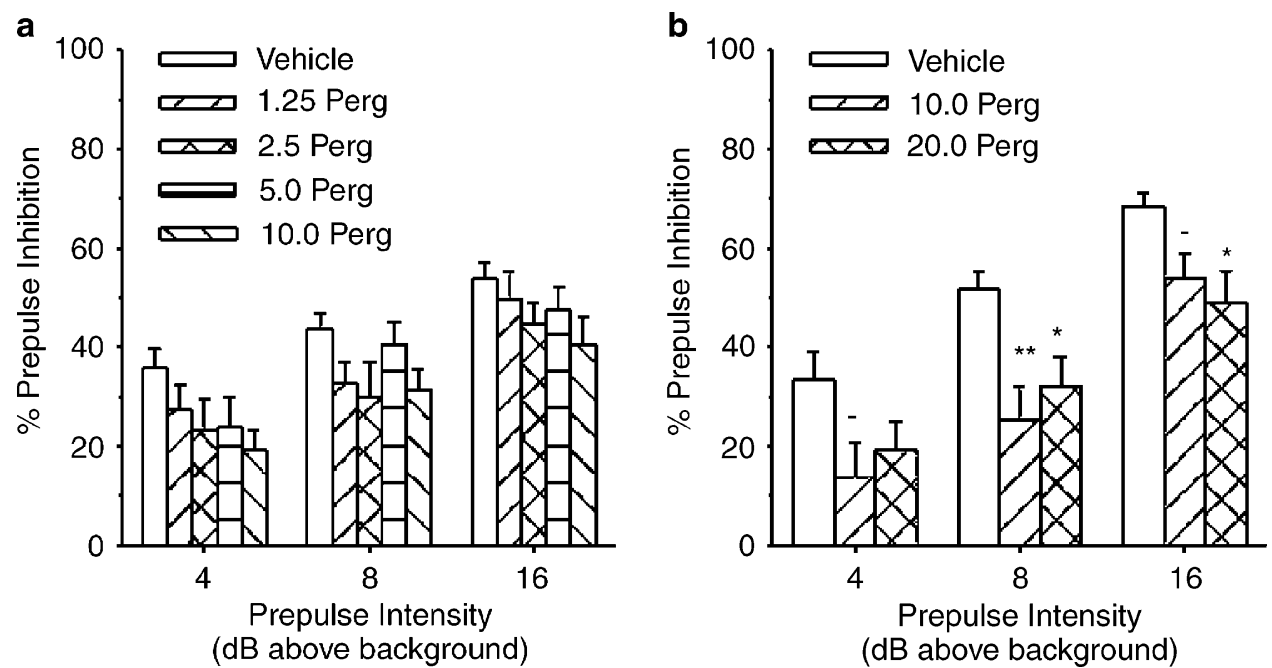

Figure $5 \mathrm{PPI}$ level in C57BL/6) mice after pretreatment with vehicle (0.9\% saline, open bars) or Perg (I.25-20.0 mg/kg pergolide, hatched bars). The mixed DA agonist pergolide showed a trend toward disrupting PPI (a); testing with higher doses revealed significant decreases in PPI (b). Values represent mean \% PPI \pm SEM and prepulse intensities are above the $65 \mathrm{~dB}$ background noise. $-p<0.10, * p<0.05$, ** $p<0.0$ I compared to vehicle control.
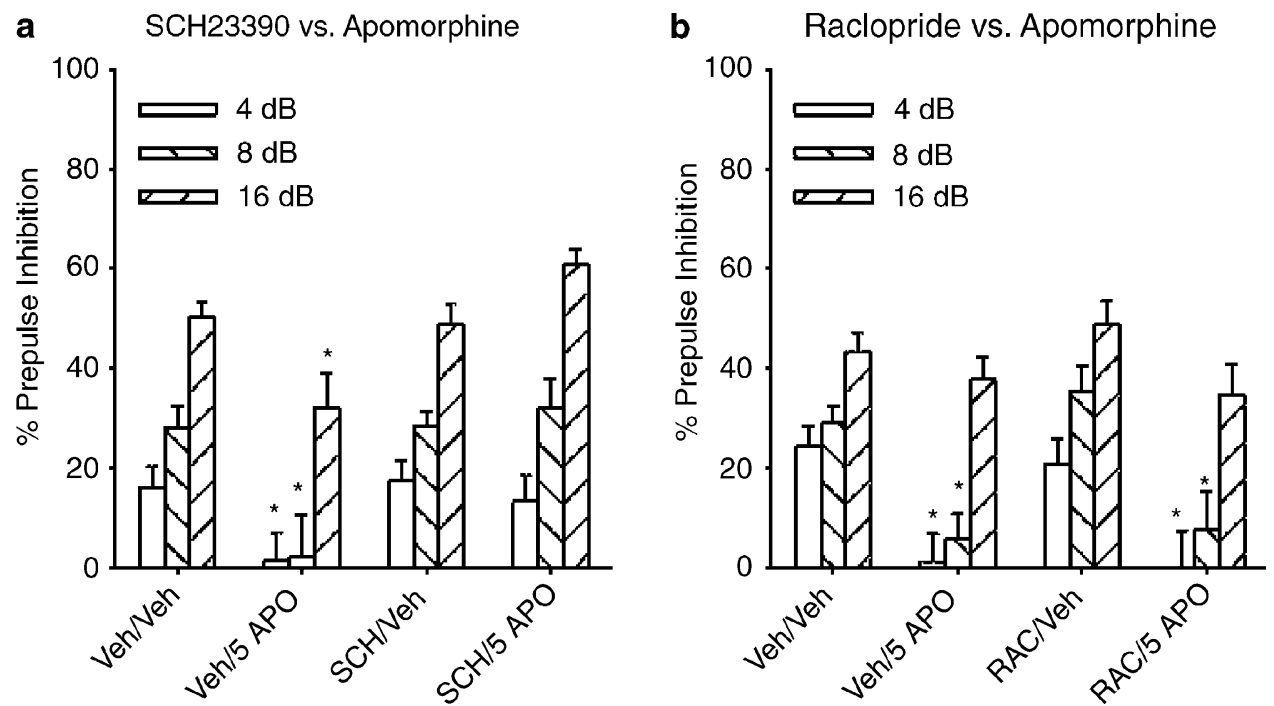

Figure 6 PPI levels in C57BL/6) mice pretreated with vehicle (0.9\% saline), SCH (1.0 mg/kg SCH23390), or RAC (3.0 mg/ $/ \mathrm{kg}$ raclopride) and treated with either vehicle (0.1\% ascorbic acid) or APO $(5.0 \mathrm{mg} / \mathrm{kg}$ apomorphine). Apomorphine significantly disrupted PPI and only the DI receptor antagonist $\mathrm{SCH} 23390$, and not the D2 antagonist raclopride, blocked the effects of apomorphine. Values represent mean \% PPI \pm SEM and prepulse intensities are above the $65 \mathrm{~dB}$ background noise. $* p<0.05$, $* * p<0.0$ l compared to vehicle control.

Similarly, SCH23390 also blocked the deficits in PPI produced by the mixed DA agonist pergolide. Unexpectedly, however, the same raclopride pretreatment that was ineffective in reducing the PPI-disruptive effect of apomorphine significantly reduced the effect of pergolide at two of the three prepulse intensities. Thus, with the exception of this latter result, the findings of the present studies indicate that D1-family rather than D2-family agonists disrupt the PPI of startle in mice.

The involvement of D1 receptors in the modulation of PPI has been supported by a growing number of reports. Several groups have shown that the mixed DA D1/D2 agonist apomorphine significantly disrupts PPI in both rats and mice (Curzon and Decker, 1998; Dulawa and Geyer, 1996; Geyer et al, 2001, in press; Mansbach et al, 1988). Here we observed similar apomorphine-induced disruptions in PPI in two strains of mice. More selective stimulation of the D1 receptor, using two different preferential D1-family agonists, also significantly reduced PPI. With SKF82958, this effect was demonstrated in two strains of mice, although higher doses of SKF82958 were less effective than lower doses in the C57BL/6J mice (see Figure 2), possibly because of a lack of specificity at higher doses. These results confirm and extend a previous report that the D1-family agonist SKF81297 $(2 \mathrm{mg} / \mathrm{kg})$ disrupted PPI in an F2 hybrid of $129 / \mathrm{SvJ} 1 \times \mathrm{C} 57 \mathrm{BL} / 6 \mathrm{~J}$ mice, an effect that may have been attenuated but was not significantly prevented in D5 receptor null mutant mice (Holmes et al, 2001). In addition, the D1 receptor antagonist SCH23390, but not the D2 receptor antagonist raclopride, blocked the disruptive effects of apomorphine on PPI in mice in the present studies. Disruptions in PPI by D1-family agonists have also 
Table 3 Effects of Pretreatment with SCH23390 or Raclopride against Apomorphine and Pergolide on Acoustic Startle Reactivity in Male C57BL/6] Mice

C57BL/6J

SCH23390 vs apomorphine

Vehicle/vehicle

Vehicle $/ 5.0 \mathrm{mg} / \mathrm{kg}$ APO

$1.0 \mathrm{mg} / \mathrm{kg} \mathrm{SCH} /$ vehicle

$1.0 \mathrm{mg} / \mathrm{kg} / 5.0 \mathrm{mg} / \mathrm{kg}$ APO

$173.3 \pm 23.7$

$95.6+9.1$ ****

$174.0 \pm 13.5$

$144.6 \pm 11.2$

Raclopride vs apomorphine

Vehicle/vehicle

Vehicle $/ 5.0 \mathrm{mg} / \mathrm{kg}$ APO

$3.0 \mathrm{mg} / \mathrm{kg}$ RAC/vehicle

$3.0 \mathrm{mg} / \mathrm{kg}$ RAC $/ 5.0 \mathrm{mg} / \mathrm{kg}$ APO

$135.9 \pm 8.4$

$74.6 \pm 7.9 * *$

$122.1 \pm 10.6$

$129.8 \pm 8.6$

SCH23390 or raclopride vs pergolide

Vehicle/vehicle

Vehicle/ $10.0 \mathrm{mg} / \mathrm{kg}$ pergolide

$1.0 \mathrm{mg} / \mathrm{kg} \mathrm{SCH} /$ vehicle

$3.0 \mathrm{mg} / \mathrm{kg}$ RAC/vehicle

$1.0 \mathrm{mg} / \mathrm{kg} \mathrm{SCH} / \mathrm{I} 0.0$ pergolide

$3.0 \mathrm{mg} / \mathrm{kg}$ RAC/I 0.0 pergolide

$141.3 \pm 15.5$

$89.9 \pm 7.0$

$191.4 \pm 20.3$

$162.8 \pm 12.9$

$132.7 \pm 16.8$

$121.4 \pm 16.9$

Values (arbitrary units) represent mean startle magnitude \pm SEM. ${ }^{*} * x<0.01$ compared to vehicle control.

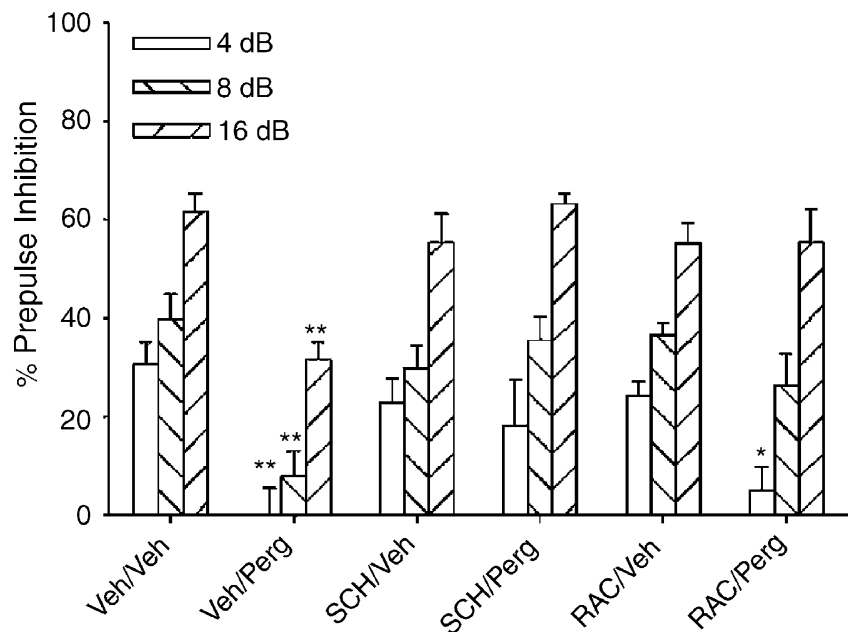

Figure $7 \mathrm{PPI}$ levels in C57BL/6) mice pretreated with vehicle $(0.9 \%$ saline), $\mathrm{SCH}$ ( $1.0 \mathrm{mg} / \mathrm{kg} \mathrm{SCH} 23390)$, or RAC $(3.0 \mathrm{mg} / \mathrm{kg}$ raclopride) and treated with either vehicle ( $0.9 \%$ saline) or Perg ( $10.0 \mathrm{mg} / \mathrm{kg}$ pergolide). PPI was significantly lowered by the mixed DA receptor agonist pergolide; both the DI receptor antagonist $\mathrm{SCH} 23390$ and the D2 antagonist raclopride blocked the effects of pergolide. Values represent mean \% PPI \pm SEM and prepulse intensities are above the $65 \mathrm{~dB}$ background noise. ${ }^{*} p<0.05$, ** $p<0.0$ I compared to vehicle control.pard

been observed in some (Swerdlow et al, 2000; Wan et al, 1996), but not all, studies in rats (Peng et al, 1990; Varty and Higgins, 1998; Wan et al, 1996; Zhang et al, 2000), albeit at relatively high and nonselective doses (Geyer et al, 2001). In contrast, much more robust disruptions of PPI were produced by relatively low doses of D1-family agonists in mice $(5 \mathrm{mg} / \mathrm{kg}$ SKF82958 produced PPI deficits in rats, while only $0.3 \mathrm{mg} / \mathrm{kg}$ was necessary to produce PPI deficits in mice). Thus, it appears possible that the direct activation of the D1 receptor produces deficits in PPI in mice. Such a conclusion is not consistent with other reports in the mouse literature, however. For example, the DA D1 receptor antagonist SCH23390 failed to reverse PPI deficits in the DA transporter knockout mice (Ralph et al, 2001). A second issue is that D2 receptor knockout mice, which have fully functional D1 receptors that can be stimulated indirectly by amphetamine, did not show amphetamine-induced disruptions in PPI (Ralph et al, 1999). If the activation of D1 receptors in the absence of D2 receptor activation is sufficient to disrupt PPI, one would expect that amphetamine would have been effective in reducing PPI in D2 knockout mice. The discrepancy between the effects of direct DA D1 agonists and previous findings in mouse PPI may be the result of using indirect $v s$ direct stimulation of DA receptors. For instance, when indirect agonists are used in mice, the released DA may not gain access to and/or activate D1 receptors as effectively as does direct stimulation of the D1 receptor by an exogenously administered agonist. There is evidence that D1 and D2 receptors work synergistically to modulate PPI in rats (Peng et al, 1990; Schwarzkopf et al, 1993; Wan et al, 1996), but such a relationship may not exist for mice in the regulation of PPI. Distinguishing the roles of the D1 and D2 receptors in the modulation of PPI in mice by using DA D2 agonists is complicated by the fact that most of these compounds have some affinity for the D3 receptor subtype as well (Sautel $e t$ al, 1995; Seeman and Van Tol, 1994). Further testing with compounds such as apomorphine, SKF82958, and pergolide in DA D1 and D2 receptor knockout mice may help determine if activation of the D1 receptor alone disrupts PPI in mice.

Despite several reports that D2/D3 agonists robustly disrupt PPI in rats (Geyer et al, 2001), quinpirole failed to produce any significant disruption of PPI in mice in the present studies. Furthermore, raclopride had no effect on the apomorphine-induced disruption of PPI at a dose shown to reverse PPI deficits in DA transporter knockout mice (Ralph et al, 2001). These findings were unexpected because there are several lines of evidence indicating that the D2 receptor subtype modulates PPI in both rats and mice. In rats, other D2-family agonists such as bromocriptine and ropinirole also disrupt PPI (Swerdlow et al, 1998), while apomorphine-induced reductions in PPI can be reversed using selective D2-family receptor antagonists such as raclopride, spiperone, and eticlopride (Hoffman and Donovan, 1994; Swerdlow et al, 1991). We have previously reported that the indirect DA agonist amphetamine fails to reduce $P P I$ in DA D2 receptor knockout mice, despite being effective in wild-type mice and in both DA D3 and D4 knockout mice (Ralph et al, 1999). These results indicate that the D2 receptor subtype is necessary for amphetamine to produce PPI deficits in mice. We have also reported that DA transporter knockout mice, with their hyperdopaminergic tone, have deficits in PPI that are reversed by the D2 antagonist raclopride and not by the D1 antagonist SCH23390, further supporting the role of the D2 receptor in the modulation of PPI in mice (Ralph et al, 2001). The lack of effect of quinpirole may represent a pharmacokinetic species difference between rats and mice, or a difference that is specific to the strains of mice examined here. There have been several reports of strain differences in mice in 
response to pharmacological manipulations (Heyser et al, 1997; Homanics et al, 1999; Miner, 1997; Schlussman et al, 1998). Here we report on two inbred strains of mice, but more extensive pharmacological studies including male and female inbred and outbred strains of mice may provide a better characterization of the effects of D2-family agonists like quinpirole and pergolide on PPI in mice.

Of the compounds tested in the current studies, only the D2-family agonists quinpirole and pergolide initially failed to produce significant disruptions in PPI similar to those produced in the rat. Our previous experience in drug studies using mice led us to believe that mice often require higher doses of a drug than the rat to produce a similar effect (eg, it takes $0.2 \mathrm{mg} / \mathrm{kg}$ amphetamine to disrupt PPI in rats, but $10 \mathrm{mg} / \mathrm{kg}$ in mice, and $0.5 \mathrm{mg} / \mathrm{kg}$ apomorphine in the rat, but $5.0 \mathrm{mg} / \mathrm{kg}$ in mice). Hence, we expanded our dose range to include higher doses for both compounds than those required in rats (eg up to $10.0 \mathrm{mg} / \mathrm{kg}$ quinpirole, while $1.0 \mathrm{mg} / \mathrm{kg}$ quinpirole reduces PPI in rats). We also manipulated several parameters, including lower doses of quinpirole, in multiple attempts to find any effect of the D2/D3 agonist on PPI. Nevertheless, we were unable to show significant disruptions in PPI in mice with quinpirole. Quinpirole has been reported to alter rates of locomotor activity in mice, although not in the same way as in rats. Quinpirole produces a biphasic response in rats, in that low doses reduce activity levels, presumably by activating D2 autoreceptors, while higher doses stimulate activity levels. However, no such behavior was found in $\mathrm{C} 57 \mathrm{BL} / 6 \mathrm{~J}$ mice, where quinpirole only lowered locomotor activity (see Halberda et al (1997) for details). These data indicate that the difference in the behavioral effects of quinpirole between rats and mice is not limited to PPI.

While the initial testing with pergolide only showed trends toward disruptions in PPI, higher doses of pergolide produced significant decreases in PPI. Whether these effects are due to activation of the $\mathrm{D} 2$ receptor remains uncertain, however, as there is evidence that pergolide has affinity for D1-family as well as D2-family receptors (Miyagi et al, 1996; Perachon et al, 1999). Furthermore, it is not clear why both SCH23390 and raclopride blocked the PPI-disruptive effects of pergolide, especially given that the same dose of raclopride did not reverse apomorphine-induced disruptions of PPI. Indeed, recent studies have shown that apomorphine disrupts PPI in D2, but not in D1, receptor knockout mice, lending further support for a more prominent role of the D1 receptor in the modulation of PPI in mice (Ralph-Williams et al, 2002). Thus, testing other compounds such as pergolide in D1 and D2 receptor knockout mice may provide additional information that will further delineate the roles of the two receptor subtypes in the regulation of PPI in mice. Taken together, these data support the idea that there may be a fundamental difference in the D2 receptor functions between rats and mice.

While almost all the DA agonists tested decreased startle response, there were dissociations between the effects of DA agonists on PPI and startle reactivity. For example, a decrease in PPI did not always accompany a decrease in startle reactivity. Both apomorphine and SKF82958 decreased PPI while reducing startle reactivity; however, quinpirole significantly lowered startle response without having any effect on PPI. Furthermore, the D1-family agonist dihydrexidine disrupted PPI while having no detectable effect on startle reactivity. Similarly, while the deficit in PPI produced by apomorphine was typically associated with reduced startle, after pretreatment with raclopride, apomorphine still reduced PPI without having any effect on startle (cf. Table 3). Examination of the raw data (ie, data from PULSE-ALONE and PREPULSE+ PULSE trials) revealed that the PPI-disruptive effects of apomorphine were not clearly separable from the startlereducing effects of apomorphine, but the effects of the more selective D1-family agonists were separable. Specifically, at least with some prepulse intensities, mean values for responses on prepulse trials in mice treated with SKF82958 or dihydrexidine exceeded the corresponding values in the vehicle-treated mice. Such a pattern of results seen with the specific D1-family agonists can be considered to reflect an unequivocal reduction in PPI, rather than merely changes in the startle reflex properties per se (Swerdlow et al, 2001a,b). These findings are consistent with other reports of dissociable effects of DA agonists on PPI and startle response in mice. Others have reported that apomorphine produces deficits in PPI in mice that are not associated with effects on startle reactivity (Curzon and Decker, 1998; Dulawa and Geyer, 1996). Amphetamine significantly decreases PPI in D3 and D4, but not in D2, receptor knockout mice, but it reduces startle response in all three genotypes of mice (Ralph et al, 1999). Thus, the effects of DA agonists on startle reactivity in mice do not appear to predict their effects on PPI. These findings provide further evidence for a dissociation between the DA pathways that regulate PPI and startle reactivity in mice.

These studies provide further characterization of the DA receptor pharmacology related to PPI in mice and highlight several key areas where more work needs to be done. In contrast to the apparent mediation by $\mathrm{D} 2$ receptors of PPI disruptions produced by exaggerated levels of synaptic DA, as in DA transporter knockout mice or after amphetamine, D1 receptors appear to be primarily responsible for the PPI-disruptive effects of direct DA agonists in mice. Further studies examining the regional, pre- $v s$ postsynaptic, and perisynaptic distributions of D1 and D2 receptors in mice will be needed to understand these apparent differences between direct and indirect DA agonist effects on PPI in mice. The present results also reveal potential species differences in the DA receptor modulation of PPI between rats and mice, where the D1 receptor might play a more prominent and independent role in the modulation of PPI in mice than in rats. It is clear that the pharmacology of PPI in mice does not always match that in rats and that more experiments are necessary to fully understand these disparities. Although strain differences in both PPI and drug effects on PPI have been reported (Bullock et al, 1997; Dulawa and Geyer, 1996, 2000; Logue et al, 1997; Paylor and Crawley, 1997), the present findings with both D1- and D2-family agonists were consistent in the two inbred strains examined. Nevertheless, further testing of DA agonists in additional inbred or outbred mouse strains is still warranted to provide a better understanding of the pharmacology related to PPI in mice. Comparisons of DA receptor distributions, 
coupling, internalization, signal transduction, and pharmacokinetic processes between mice and rats may also help to explain species differences in the dopaminergic modulation of PPI.

The present findings also have implications for the possible use of DA agonist effects on PPI in mice in developing predictive models of antipsychotic effects in humans, an approach that has demonstrated considerable predictive validity in rats (Geyer et al, 2001; Swerdlow and Geyer, 1998). Previous reports have suggested that antipsychotic drugs, including D2-family antagonists, are effective in increasing PPI in mice that have not first been treated with a DA agonist (Olivier et al, 2001; Ouagazzal et al, 2001), as is typically done in rat tests of antipsychotic action (Geyer et al, 2001; Swerdlow and Geyer, 1998). Thus, the effective study of antipsychotic treatments may require substantially different strategies when using mice rather than rats. Finally, the apparent differences in the effects of DA agonists on PPI in mice $v s$ rats raises the question as to which species will be more predictive of DA agonist effects on PPI in humans. By virtue of the crossspecies comparability of PPI between rodents and humans, it is feasible to address this question directly by studying the effects of selected DA agonists on PPI in humans (Braff et al, 2001; Swerdlow et al, 2002). Although the data from such human studies remain insufficient to support definitive conclusions, initial studies of dopaminergic, serotonergic, and glutamatergic drugs that disrupt PPI in rodents have not consistently observed similar effects in humans, as discussed extensively elsewhere (Braff et al, 2001; Swerdlow et al, 2002). With respect to the direct DA agonists examined here, no study of D1-family agonist effects on PPI in humans has appeared, but a recent report failed to detect any significant effect of the D2-family agonist pergolide on human PPI (Braff et al, 2001; Swerdlow et al, 2002). The question as to which rodent species, mouse or rat, will be the more predictive of pharmacological effects on PPI in humans must be considered separately for each class of compounds. It is conceivable that mice and humans will be more similar in response to some drugs, while rats and humans are more similar when other drugs are examined. The present findings indicate that further cross-species comparisons of the pharmacology of PPI are essential. Eventually, the elucidation of species differences in the dopaminergic regulation of PPI is likely to provide a better understanding of the neuropathology of sensorimotor gating disorders seen in psychiatric populations and may ultimately lead to new drug therapies to treat these disease states.

\section{ACKNOWLEDGEMENTS}

The authors thank David Gallagher and Mahálah Buell for their technical assistance and Dr Neal Swerdlow for comments on an earlier draft of this manuscript. These studies were supported by the Veterans Affairs VISN 22 Mental Illness Research, Education, and Clinical Center, and grants from the National Institute on Drug Abuse (DA02925) and the National Institute of Mental Health (F31-MH12806, MH61326, MH42228).
MA Geyer holds an equity interest in San Diego Instruments.

\section{REFERENCES}

Braff DL, Geyer MA, Swerdlow NR (2001). Human studies of prepulse inhibition of startle: normal subjects, patient groups, and pharmacological studies. Psychopharmacology (Berl) 156: 234-258.

Bullock AE, Slobe BS, Vazquez V, Collins AC (1997). Inbred mouse strains differ in the regulation of startle and prepulse inhibition of the startle response. Behav Neurosci 111: 1353-1360.

Caine SB, Geyer MA, Swerdlow NR (1995). Effects of D3/D2 dopamine receptor agonists and antagonists on prepulse inhibition of acoustic startle in the rat. Neuropsychopharmacology 12: 139-145.

Curzon P, Decker MW (1998). Effects of phencyclidine (PCP) and $(+)$ MK-801 on sensorimotor gating in CD-1 mice. Prog Neuropsychopharmacol Biol Psychiatry 22: 129-146.

Darney KJJ, Lewis MH, Brewster WK, Nichols DE, Mailman RB (1991). Behavioral effects in the rat of dihydrexidine, a highpotency, full-efficacy D1 dopamine receptor agonist. Neuropsychopharmacology 5: 187-195.

Dulawa SC, Geyer MA (1996). Psychopharmacology of prepulse inhibition in mice. Chin J Physiol 39: 139-146.

Dulawa SC, Geyer MA (2000). Effects of strain and serotonergic agents on prepulse inhibition and habituation in mice [in process citation]. Neuropharmacology 39: 2170-2179.

Dulawa SC, Hen R, Scearce-Levie K, Geyer MA (1997). Serotonin1B receptor modulation of startle reactivity, habituation, and prepulse inhibition in wild-type and serotonin1B knockout mice. Psychopharmacology (Berl) 132: 125-134.

Geyer MA, Krebs-Thomson K, Braff DL, Swerdlow NR (2001). Pharmacological studies of prepulse inhibition models of sensorimotor gating deficits in schizophrenia: a decade in review. Psychopharmacology 156: 117-154.

Geyer MA, McIlwain KL, Paylor R (in press). Mouse genetic models for prepulse inhibition: an early review. Mol Psychiatry.

Geyer MA, Swerdlow NR (1998). Measurement of the startle response and its use in preclinical measures of prepulse inhibition and habituation. In: Crawley JN, Skolnick P (eds). Current Protocols in Neuroscience. Vol 2. John Wiley \& Sons, Inc: New York, 8.7.1-8.7.15.

Geyer MA, Swerdlow NR, Mansbach RS, Braff DL (1990). Startle response models of sensorimotor gating and habituation deficits in schizophrenia. Brain Res Bull 25: 485-498.

Graham FK (1975). Presidential Address, 1974. The more or less startling effects of weak prestimulation. Psychophysiology 12: 238-248.

Halberda JP, Middaugh LD, Gard BE, Jackson BP (1997). DAD1and DAD2-like agonists effects on motor activity of C57 mice: differences compared to rats. Synapse 26: 81-92.

Heyser CJ, McDonald JS, Beauchamp V, Koob GF, Gold LH (1997). The effects of cocaine on operant responding for food in several strains of mice. Psychopharmacology (Berl) 132: 202-208.

Hoffman DC, Donovan H (1994). D1 and D2 dopamine receptor antagonists reverse prepulse inhibition deficits in an animal model of schizophrenia. Psychopharmacology (Berl) 115: 447453.

Hoffman HS, Ison JR (1980). Reflex modification in the domain of startle: I. Some empirical findings and their implications for how the nervous system processes sensory input. Psychol Rev 87: 175-189.

Holmes A, Hollon TR, Gleason TC, Liu Z, Dreiling J, Sibley DR, Crawley JN (2001). Behavioral characterization of dopamine D5 receptor null mutant mice. Behav Neurosci 115: 1129-1144. 
Homanics GE, Quinlan JJ, Firestone LL (1999). Pharmacologic and behavioral responses of inbred C57BL/6J and strain 129/SvJ mouse lines. Pharmacol Biochem Behav 63: 21-26.

Kebabian JW, Calne DB (1979). Multiple receptors for dopamine. Nature 277: 93-96.

Logue SF, Owen EH, Rasmussen DL, Wehner JM (1997). Assessment of locomotor activity, acoustic and tactile startle, and prepulse inhibition of startle in inbred mouse strains and F1 hybrids: implications of genetic background for single gene and quantitative trait loci analyses. Neuroscience 80: 1075-1086.

Mansbach RS, Geyer MA, Braff DL (1988). Dopaminergic stimulation disrupts sensorimotor gating in the rat. Psychopharmacology 94: 507-514.

Miner LL (1997). Cocaine reward and locomotor activity in C57BL/ $6 \mathrm{~J}$ and $129 / \mathrm{SvJ}$ inbred mice and their F1 cross. Pharmacol Biochem Behav 58: 25-30.

Miyagi M, Itoh F, Taya F, Arai N, Isaji M, Kojima M, Ujiie A (1996). Dopamine receptor affinities in vitro and stereotypic activities in vivo of cabergoline in rats. Biol Pharm Bull 19: 1210-1213.

Mottola DM, Brewster WK, Cook LL, Nichols DE, Mailman RB (1992). Dihydrexidine, a novel full efficacy D1 dopamine receptor agonist. J Pharmacol Exp Ther 262: 383-393.

Olivier B, Leahy C, Mullen T, Paylor R, Groppi VE, Sarnyai Z, Brunner D (2001). The DBA/2J strain and prepulse inhibition of startle: a model system to test antipsychotics? Psychopharmacology (Berl) 156: 284-290.

Ouagazzal AM, Jenck F, Moreau JL (2001). Drug-induced potentiation of prepulse inhibition of acoustic startle reflex in mice: a model for detecting antipsychotic activity? Psychopharmacology 156: 273-283.

Paylor R, Crawley JN (1997). Inbred strain differences in prepulse inhibition of the mouse startle response. Psychopharmacology (Berl) 132: 169-180.

Peng RY, Mansbach RS, Braff DL, Geyer MA (1990). A D2 dopamine receptor agonist disrupts sensorimotor gating in rats. Implications for dopaminergic abnormalities in schizophrenia. Neuropsychopharmacology 3: 211-218.

Perachon S, Schwartz JC, Sokoloff P (1999). Functional potencies of new antiparkinsonian drugs at recombinant human dopamine D1, D2, and D3 receptors. Eur J Pharmacol 366: 293-300.

Ralph RJ, Paulus MP, Fumagalli F, Caron MG, Geyer MA (2001). Prepulse inhibition deficits and perseverative motor patterns in dopamine transporter knock-out mice: differential effects of D1 and D2 receptor antagonists. J Neurosci 21: 305-313.

Ralph RJ, Varty GB, Kelly MA, Wang YM, Caron MG, Rubinstein M, Grandy DK, Low MJ, Geyer MA (1999). The dopamine D2, but not D3 or D4, receptor subtype is essential for the disruption of prepulse inhibition produced by amphetamine in mice. $J$ Neurosci 19: 4627-4633.

Ralph-Williams RJ, Lechmann-Masten V, Otero-Corchon V, Low MJ, Geyer MA (2002). Differential effects of direct and indirect dopamine agonists on prepulse inhibition: a study in D1 and D2 receptor knock-out mice. J Neurosci 22: in press.
Sautel F, Griffon N, Levesque D, Pilon C, Schwartz JC, Sokoloff P (1995). A functional test identifies dopamine agonists selective for D3 versus D2 receptors. Neuroreport 6: 329-332.

Schlussman SD, Ho A, Zhou Y, Curtis AE, Kreek MJ (1998). Effects of 'binge' pattern cocaine on stereotypy and locomotor activity in C57BL/6J and 129/J mice. Pharmacol Biochem Behav 60: 593-599.

Schwarzkopf SB, Bruno JP, Mitra T (1993). Effects of haloperidol and SCH 23390 on acoustic startle and prepulse inhibition under basal and stimulated conditions. Prog Neuropsychopharmacol Biol Psychiatry 17: 1023-1036.

Seeman P, Van Tol HH (1994). Dopamine receptor pharmacology. Trends Pharmacol Sci 15: 264-270.

Swerdlow NR, Eastvold A, Karban B (2002). Dopamine agonist effects on startle and sensorimotor gating in normal male subjects: time course studies. Psychopharmacology (Berl) 161: 189-201.

Swerdlow NR, Geyer MA (1993). Clozapine and haloperidol in an animal model of sensorimotor gating deficits in schizophrenia. Pharmacol Biochem Behav 44: 741-744.

Swerdlow NR, Geyer MA (1998). Using an animal model of deficient sensorimotor gating to study the pathophysiology and new treatments of schizophrenia. Schizophr Bull 24: 285-301.

Swerdlow NR, Keith VA, Braff DL, Geyer MA (1991). Effects of spiperone, raclopride, SCH 23390 and clozapine on apomorphine inhibition of sensorimotor gating of the startle response in the rat. J Pharmacol Exp Ther 256: 530-536.

Swerdlow NR, Martinez ZA, Hanlon FM, Platten A, Farid M, Auerbach P, Braff DL, Geyer MA (2000). Toward understanding the biology of a complex phenotype: rat strain and substrain differences in the sensorimotor gating-disruptive effects of dopamine agonists. J Neurosci 20: 4325-4336.

Swerdlow NR, Platten A, Kim YK, Gaudet I, Shoemaker J, Pitcher L, Auerbach P (2001a). Sensitivity to the dopaminergic regulation of prepulse inhibition in rats: evidence for genetic, but not environmental determinants. Pharmacol Biochem Behav 70: 219-226.

Swerdlow NR, Platten A, Shoemaker J, Pitcher L, Auerbach P (2001b). Effects of pergolide on sensorimotor gating of the startle reflex in rats. Psychopharmacology (Berl) 158: 230-240.

Swerdlow NR, Taaid N, Oostwegel JL, Randolph E, Geyer MA (1998). Towards a cross-species pharmacology of sensorimotor gating: effects of amantadine, bromocriptine, pergolide and ropinirole on prepulse inhibition of acoustic startle in rats. Behav Pharmacol 9: 389-396.

Varty GB, Higgins GA (1998). Dopamine agonist-induced hypothermia and disruption of prepulse inhibition: evidence for a role of D3 receptors?. Behav Pharmacol 9: 445-455.

Wan FJ, Taaid N, Swerdlow NR (1996). Do D1/D2 interactions regulate prepulse inhibition in rats?. Neuropsychopharmacology 14: $265-274$

Zhang J, Forkstam C, Engel JA, Svensson L (2000). Role of dopamine in prepulse inhibition of acoustic startle. Psychopharmacology (Berl) 149: 181-188. 